\title{
Moraxella catarrhalis, Beta-Lactamase Negative
}

National Cancer Institute

\section{Source}

National Cancer Institute. Moraxella catarrhalis, Beta-Lactamase Negative. NCI

Thesaurus. Code C123517.

Any bacterial species identified as Moraxella catarrhalis that does not produce the enzyme beta-lactamase. 